\title{
A Study of the Distribution of a Bacterial Community in Biological-Activated Carbon (BAC)
}

\author{
Hong-Ki Park*, Eun-Young Jung, Dong-Jin Cha, Jung-A Kim and Jae-Hoon Bean
}

Water Quality Institute, Water Works HQ of Busan Metropolitan City, Kyoungnam 621-813, Korea

Received August 2, 2012 /Revised August 24, 2012 / Accepted September 17, 2012

\begin{abstract}
The use of biological-activated carbon (BAC) processes in water treatment involves biofiltration, which maximizes the bacteria's capabilities to remove organic matter. In this study, the distribution of the bacterial community was assessed in response to different types of BAC processes applied downstream in the Nakdong River. The bacterial biomass and activity were $1.20 \sim 34.0 \times 10^{7} \mathrm{CFU} / \mathrm{g}$ and $0.61 \sim 1.10 \mathrm{mg}-\mathrm{C} / \mathrm{m}^{3} \cdot \mathrm{hr}$ in coal-based $\mathrm{BAC}$, respectively. The attachment of the bacterial biomass and the removal efficiency of the organic carbon were greatest with the coal-based activated carbon. The bacteria attached to each activated carbon material were detected in the order of Pseudomonas genus, Chryseomonas genus, Flavobacterium genus, Alcaligenes genus, Acinetobacter genus, and Spingomona genus. Pseudomonas cepacia was the dominant species in the coal-based materials, and Chryseomonas luteola was the dominant species in the wood-based material.
\end{abstract}

Key words : Biologicl Activated Carbon (BAC), bacterial community, Pseudomonas, Chryseomonas

\section{서 론}

현재 적용되고 있는 고도처리방법중의 하나인 활성탄 여과 법은 활성탄의 다공성에 의해 수중의 각종 유해물질들이 활성 탄에 잘 흡착되므로 기존의 급속여과법에서는 제거되지 않는 용해성 유기물, 미량 유기화합물, 암모니아성 질소, 철, 망간, 이취미 원인 물질, 소독 부산물 등의 제거에 매우 효과적이어 서 구미 각국에서도 고도정수처리에 많이 이용하고 있다[17]. 활성탄은 다공성 여재(media)로 목재(wood), 야자각 (coconut), 역청탄(bituminous coal), 갈탄(lignite) 등을 원료로 하여 제조되며, 정수 및 하수처리 공정에서도 흡착제로 널리 이용되고 있고, 보통 탁질이나 유기물 농도부하가 적은 여과 공정 후단에 입상활성탄(granular activated carbon, $\mathrm{GAC}$ ) 형 태로 많이 적용된다[8]. 또한 GAC 공정에서 GAC 파과점을 지나 지속적으로 운전한 결과, GAC 표면에 부착된 미생물의 응집체(aggregation)에 의한 생물학적 분해 작용으로 인하여 용존유기탄소(dissolved organic carbon, DOC)가 제거된다는 보고가 있다[3]. 이것을 생물활성탄(biologically activated carbon, $\mathrm{BAC}$ ) 공정이라고 하며, $\mathrm{GAC}$ 에 의한 유기물의 흡착 이외 에 미생물의 생물학적 작용을 조합한 $\mathrm{BAC}$ 처리공정이 현재 전 세계적으로 널리 이용되고 있다.

$\mathrm{BAC}$ 공정의 장점으로는 첫째, 수중에 존재하는 다양한 오 염물질들에 대한 높은 제거능이고 $[4,11,15,23]$, 둘째, BAC 처리 수는 낮은 염소요구량을 나타내어 소독부산물의 생성이 적고,

*Corresponding author

Tel : +82-51-669-4643, Fax : +82-51-669-4609

E-mail : phk111@korea.kr
배 · 급수관망에서 미생물 재성장능이 낮다 $[7,21,25]$. 또한, 셋 째로 흡착능이 소진된 $\mathrm{GAC}$ 의 효율적인 생물학적 재생으로 인한 $\mathrm{GAC}$ 의 사용기간 연장이다[10,20]. $\mathrm{BAC}$ 의 입자 표면은 세균이 부착하는데 아주 적절하고 또한 원수에는 세균의 영양 분이 될 수 있는 각종 유기 및 무기물질이 포함되어 있어 세균 의 번식을 가능하게 한다. 정수처리에서 생물활성탄 공정은 미생물의 유기물 제거능을 극대화시킨 일종의 생물여과 공정 으로 이전부터 국내·외에서 널리 사용되고 있는 정수처리 기법이며, 최근에는 멤브레인 공정과 조합하여 새로운 정수처 리 공정으로 부각되고 있다[1,8].

세균은 활성탄의 macro pore (500 ̊ 이상)에 대부분 부착 되며 이곳에서 효소를 생산하며 이 효소들은 micro pore $(20$ $\AA$ 이하)에도 쉽게 확산되어 흡착된 기질과 반응하여 각종 유 기물들을 분해하는 등 활성탄의 흡착 능력을 재생시키는 역할 도 한다. $\mathrm{BAC}$ 에 부착 - 서식하고 있는 세균은 낮은 농도의 유 기물과 영양염류를 이용하여 생장하고 이 과정에서 체내의 영양염류를 고농도로 축적하게 된다. 세균은 빛, 수온, 기질, 효소, $\mathrm{pH}$ 등에 영향을 받아서 부착 세균의 구성종 및 생체량에 많은 차이를 유발하여 $\mathrm{BAC}$ 공정의 효율에 많은 영향을 미친 다고 알려져 있다[9,12,14].

Kihn 등[12]이 1일 최대 100톤 처리 용량의 Pilot-plant을 대상으로 $\mathrm{BAC}$ 공정에서 활성탄 재질별로 수질개선 및 부착세 균 분포특성을 조사한 결과 $\mathrm{BAC}$ 활성탄 종류 및 부착세균의 생체량과 활성도에 따라 유기물 제거농도에 차이를 보이는 것으로 조사되었다. 따라서 본 연구에서는 3 개 정수장에서 사 용하고 있는 생물활성탄에 대한 부착세균 연구를 통해 $\mathrm{BAC}$ 처리에 의한 유기물 제거효율과 세균과의 상관관계를 비교 
분석하여 $\mathrm{DOC}$ 등 유기물 제거효율과 정수장 및 활성탄 종류 별로 부착세균의 군집구조 특성을 조사하였다. 그리고 이 결 과를 토대로 고도 정수처리시설의 효율 평가 및 문제점 개선 시 기초자료로 활용하고자 하였다.

\section{재료 및 방법}

\section{조사기간 및 $\mathrm{DOC}$ 분석}

조사기간은 1년(2011. 1월 2011. 12월)으로 하였으며, 조사 주기는 수질인자 항목인 $\mathrm{DOC}$ 의 경우 월 2회, 부착세균 분포 조사는 월 1회 간격으로 조사하였다. DOC (dissolved organic carbon)는 시료를 $0.2 \mu \mathrm{m}$ 멤브레인 필터(Sartorius, Germany) 로 여과한 후 그 여액을 TOC analyzer (Sievers 820, Sievers, U.S.A.)로 분석함으로써 조사하였다.

\section{세균 생체량 및 종 동정}

세균의 생체량(biomass)은 $\mathrm{BAC}$ 의 습중량 $1 \mathrm{~g}$ 을 실험실내 의 상온에서 하루 정도 건조시켜 희석수 $20 \mathrm{ml}$ 를 첨가한 후 초음파 처리 $(3 \mathrm{~min}, 37 \mathrm{kH}, 190 \mathrm{~W})$ 하여 세균을 탈리시킨 다음 $\mathrm{R} 2 \mathrm{~A}$ agar (Difco) 평판배지에 시료 $1 \mathrm{ml}$ 를 단계적으로 희석 도말한 후 $25^{\circ} \mathrm{C}$ 배양기에서 2주간 배양하여 습중량 $1 \mathrm{~g}$ 당 colony형성 세균수로 표시하였다[18].

세균의 동정은 형성된 colony의 형태학적 특징을 관찰하여 서로 다른 colony를 종속영양세균 분리배지인 R2A에 획선 도 말하여 순수 분리하였다. 순수 분리된 세균은 API $20 \mathrm{NE} \mathrm{Kit}$ (bioMerieux, France)로 확인한 후 Bergey's manual의 분류체 계에 따라 속 혹은 종명까지 분류 동정하였다[13].

\section{세균 활성도 측정}

세균의 활성도(bacterial production)는 ${ }^{3} \mathrm{H}$-thymidine이 DNA에 흡수되는 정도로 구하였다[9]. 먼저 BAC 습중량 $1 \mathrm{~g}$ 을 초음파 처리하여 세균을 탈리시킨 시료 $2 \mathrm{ml}$ 에 $200 \mathrm{nM}$ [methyl ${ }^{3} \mathrm{H}$ ] thymidine 용액(specific activity: 40 50 $\mathrm{Ci} / \mathrm{mmol}) 1 \mathrm{ml}$ 와 $200 \mathrm{nM}$ cold thymidine 용액 $1 \mathrm{ml}$ 를 첨가 한 후 2,000 rpm으로 교반하여 4 시간 배양하였다. ATP 용액 $(25 \mathrm{~g} / \mathrm{l}) 100 \mathrm{ul}, \mathrm{DNA}$ 용액( $0.75 \mathrm{~g} / \mathrm{l}) 100 \mu \mathrm{l}$ 그리고 $1 \mathrm{~N} \mathrm{NaOH}$ $2 \mathrm{ml}$ 를 첨가하여 $100^{\circ} \mathrm{C}$ 에서 1 시간 동안 가열하여 $\mathrm{DNA}$ 를 추 출한 후 잠시 냉각시키고 $3,000 \mathrm{rpm}$ 에서 10 분간 원심분리하였 다. 상등액 $1 \mathrm{ml}$ 에 ice-cold $10 \%$ trichloroacetic acid $5 \mathrm{ml}$ 를 첨가하여 반응을 종료시키고 15 분 정도 냉각시킨 후 $0.2 \mu \mathrm{m}$ 멤브레인 필터로 여과하였다. 이 여지를 vial에 넣고 건조시킨 후 ethyl acetate $1 \mathrm{ml}$ 와 scintillation cocktail (Aquasol-2, Packard Co.) $10 \mathrm{ml}$ 주입하여 liquid scintillation analyzer (PerkinElmer, Quantulus 1220)로 방사선량을 측정하였다. 얻 어진 DPM (disintergrate per minute) 값으로부터 얻어진 식 을 이용하여 incorporation된 thymidine의 양을 계산하였다
$[5,18]$

\section{주사전자현미경(SEM) 관찰}

생물활성탄 입자 표면에 부착된 세균들을 관찰하기 위한 주사전자현미경(Scanning Electron Microscope; SEM) 분석은 건조시킨 $\mathrm{BAC}$ 시료에 $10 \mathrm{ml}$ 의 $2.5 \%$ glutaraldehyde 용액(0.1 $\mathrm{M}$ sodium caccodylate buffer ( $\mathrm{pH}$ 6.8)로 희석)을 첨가하여 $4{ }^{\circ} \mathrm{C}$ 에서 2시간 동안 전 고정한 후 $0.1 \mathrm{M}$ sodium caccodylate buffer (pH 6.8) $10 \mathrm{ml}$ 로 전 고정과 같은 조건에서 세정하였다. $1 \% \mathrm{OsO}_{4}$ 용액 $(0.1 \mathrm{M}$ sodium caccodylate buffer $(\mathrm{pH}$ 6.8)로 희석) $5 \mathrm{ml}$ 를 첨가하여 후 고정시킨 후 다시 $0.1 \mathrm{M}$ sodium caccodylate buffer (pH 6.8) $10 \mathrm{ml}$ 로 실온에서 세정하였다. 그리고 각 $10 \mathrm{ml}$ 의 $30,50,70,80,90,95,100 \%$ ethanol로 각각 의 농도에서 10 분간씩 탈수시킨 후[19], 부산시 부산진구 당감 동에 위치한 한국 신발피혁 연구소에 SEM 촬영을 의뢰하여 $\mathrm{BAC}$ 입자에 부착된 세균을 관찰하였다.

\section{결과 및 고찰}

\section{정수장별 정수공정 운전조건}

Table 1에 각 정수장의 정수공정별 운전조건을 제시하였다. 명장 정수장은 고속 원형식을 이용한 정수처리, 화명 정수장 은 맥동식과 횡류식 침전지를 이용하여 정수처리를 실시하고 있으며, 덕산 정수장의 경우 3 개 정수계열로 나뉘어져 있는데 모두 맥동식 방식을 이용하여 정수처리를 수행하고 있다. 명 장, 화명, 덕산 정수장의 정수 생산능력은 각각 28 만톤, 60 만 톤, 155 만톤/일로 덕산 정수장의 1 일 정수 생산능력이 가장 큰 것으로 나타났다.

\section{정수장별 생물활성탄 재질 특성}

Table 2에 각 정수장 고도처리시설의 제원을 나타냈다. 명 장 정수장에서 사용하는 활성탄은 모두 목탄계 활성탄으로 98년 12월 활성탄 여과지에 충진된 활성탄을 재생하지 않고 계속 사용하고 있다. 화명 정수장의 활성탄 여과지는 도입초

Table 1. Operating conditions of water treatment process using biological activated carbons

\begin{tabular}{lccc}
\hline \multirow{2}{*}{ Parameters } & \multicolumn{3}{c}{ Operating conditions } \\
\cline { 2 - 4 } & MJ & HM & DS \\
\hline Empty Bed Contact Time (min) & 15.1 & 12.2 & 28.0 \\
Linear Velocity (m/h) & 16.5 & 17.3 & 6.0 \\
Bed depth (m) & 4.1 & 4.0 & 3.0 \\
Backwashing time (min) & 60 & 60 & 60 \\
Expansion rate (\%) & 25 & 20 & 24 \\
Pre-Ozone dose (mg/l) & 0.6 & 0.6 & 0.5 \\
Post-Ozone dose (mg/l) & 0.4 & 0.4 & 0.5 \\
\hline
\end{tabular}

MJ: Myungjang Water Plant, HM: Hoamyung Water Plant, DS: Duksan Water Plant 
Table 2. Specification of granular activated carbons

\begin{tabular}{lcc}
\hline \multirow{2}{*}{ Items } & \multicolumn{2}{c}{ Properties } \\
\cline { 2 - 3 } & Coal & Wood \\
\hline Apparent density $\left(\mathrm{g} / \mathrm{cm}^{3}\right)$ & 0.43 & 0.23 \\
Hardness number $(\%)$ & 98 & - \\
Iodine value $(\mathrm{mg} / \mathrm{g})$ & 1050 & 950 \\
MB adsorption $(\mathrm{ml} / \mathrm{g})$ & 256 & 250 \\
Residual material after mesh $(8 \times 32$ mesh) & 99.5 & 98 \\
Specific surface area $\left(\mathrm{m}^{2} / \mathrm{g}\right)$ & 1100 & 1611 \\
Total pore volume $\left(\mathrm{cm}^{3} / \mathrm{g}\right)$ & 0.61 & 1.21 \\
Mean pore radius $(\AA)$ & 23 & 28 \\
\hline
\end{tabular}

기에는 총 18 지중 석탄계 4 지 나머지는 야자계로 사용하였으 나 이후 일부 하부집수장치 파손과 활성탄 역세척 효율을 높 이기 위한 2006년 말에 공세시설을 도입한 이후 2007년부터 활성탄 탄종도 석탄계 활성탄이 야자계 활성탄에 비해 처리효 율이 높아 계속적으로 야자계를 석탄계로 교체해오고 있다. 화명 정수장에서는 2010년에 6지를 재생하였고, 약 1지를 신 탄으로 재중전하여 현재 운영 중에 있다. 덕산 정수장은 1정수 계통은 20지, 2정수 계통은 18 지, 3정수 계통은 16지로 총 54지 의 입상활성탄 여과지로 구성되어 있으며, 1 정수 계통과 2정 수 계통에 각각 1지의 야자계 입상활성탄을 제외하면 나머지 52지의 입상활성탄은 모두 석탄계 입상활성탄을 이용하여 정 수처리하고 있다. 2010년 1정수에 12지 2정수에 8지를 재생하 였으며 재생중에 손실된 탄을 신탄으로 보충하여 사용 중에 있다.

\section{정수장별(활성탄 재질별) DOC 제거능}

수중에 존재하는 용존 유기탄소 즉 $\mathrm{DOC}$ 는 주로 수계에 존 재하는 세균의 물질대사작용에 의하여 제거되므로[2] 수중 미 생물이 많이 부착 서식하고 있는 $\mathrm{BAC}$ 에 의해 어느 정도 제거 되는지를 조사하였다. 조사기간 동안 명장, 화명 및 덕산 원수 의 평균 $\mathrm{DOC}$ 는 각각 $2.81,2.79,2.67 \mathrm{mg} / \mathrm{l}, \mathrm{BAC}$ 유입수인 후오존수의 평균 $\mathrm{DOC}$ 는 $1.54 ~ 1.69 \mathrm{mg} / 1$ 이었으며 $\mathrm{BAC}$ 의 $\mathrm{DOC}$ 에 대한 제거율은 대략 $2.5 \sim 36.8 \%$ 로 나타났다. 그중에서 도 석탄계 $\mathrm{BAC}$ 인 덕산 정수장 유출수가 약 $36.8 \%$ 로 다른 $\mathrm{BAC}$ 유출수 보다 높은 것으로 나타났으며, 화명(석탄계), 명 장(목탄계) 순으로 조사되었다(Fig. 1). 그리고 계절별 DOC 평 균 제거율은 5 월이 가장 높게 나타났으며 그 외(3월, 8월 및 11월)는 모두 비슷한 경향을 보이는 것으로 나타났는데 이는 부착세균의 활성도 차이에 의해 기인한 것으로 판단된다[25].

$\mathrm{DOC}$ 대부분의 용존 유기물은 난분해성 물질이라 생각되며 입자성 유기물보다 5 10배 풍부하게 존재한다고 알려져 있으 며[6], 용존 유기물중 생분해 가능한 유기탄소는 주로 수중의 식물플랑크톤에 의해 세포 밖으로 배출되어진 것과 오존 등에 의해 부식물질이 분해되어 생성되어진 것 등이 있다. $\mathrm{BAC}$ 공 정에 있어서 유기물의 초기 흡착능과 운전기간이 경과함에
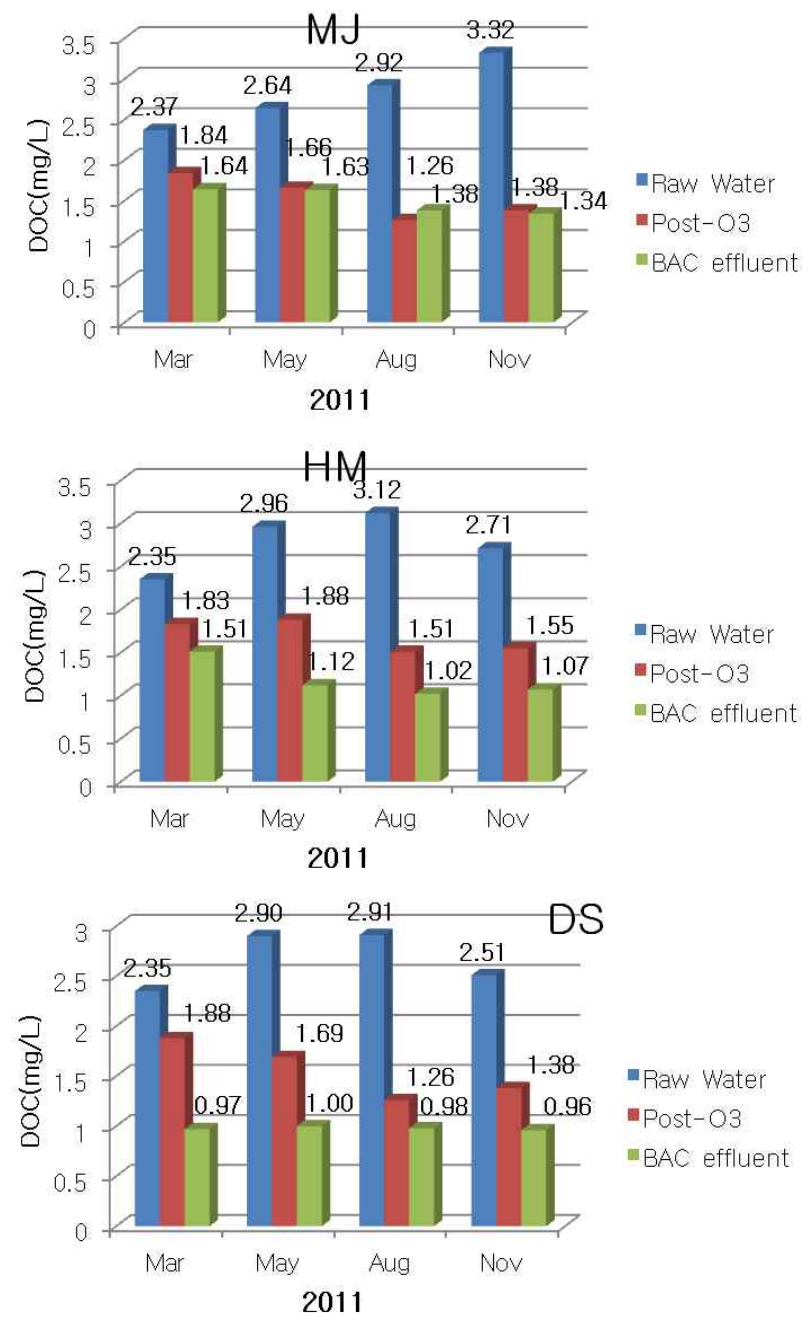

Fig. 1. Removal efficiency of dissolved organic carbon in different BAC types. MJ: Myungjang Water Plant, HM: Hoamyung Water Plant, DS: Duksan Water Plant

따라 생분해능의 증가 등을 파악하는 것은 중요하다. 일반적 으로 활성탄의 유기물 흡착 능력은 Freundlich 등온흡착 실험 결과 흡착계수 $1 / \mathrm{n}$ 의 값이 2 보다 큰 값을 보이면 등온흡착선 의 기울기가 크게 되어 활성탄을 증가시켜도 흡착물질이 잘 제거되지 않으며, $1 / \mathrm{n}$ 의 값이 $0.1 \sim 0.5$ 일 때 흡착되기 쉽고 이 범위내에서는 $\mathrm{K}$ 값이 클수록 효과적인 것으로 알려져 있다. 야자계와 석탄계 $\mathrm{BAC}$ 는 $1 / \mathrm{n}$ 의 값은 비슷하고 석탄계의 $\mathrm{K}$ 값 이 더 크므로 $\mathrm{DOC}$ 는 석탄계에 가장 쉽게 흡착되고 반면에 목탄계는 DOC 흡착이 효과적이지 않음을 밝힌 Park [16]의 연구결과와 이번 조사는 부합되는 것으로 판단된다.

\section{정수장별(활성탄 재질별) 부착세균 생체량 및 활성도 분포}

$\mathrm{BAC}$ 에 부착된 세균의 생체량은 전반적으로 $\mathrm{BAC}$ 여과 표 층에서 $0.30 \sim 34 \times 10^{7} \mathrm{CFU} / \mathrm{g}$, 저층에서 $1.11 \sim 30 \times 10^{5} \mathrm{CFU} / \mathrm{g}$ 범 위를 보였는데(Table 3), 이는 Kihn 등[12]이 실시한 Pilot- 
Table 3. Variations of bacterial biomass in different BAC types

\begin{tabular}{lccc}
\hline Sampling sites & Sampling point & Bacteria biomass $(\mathrm{CFU} / \mathrm{g})$ & Bacterial production $\left(\mathrm{mg}-\mathrm{C} / \mathrm{m}^{3} \cdot \mathrm{h}\right)$ \\
\hline MJ BAC & Upper part & $0.53 \sim 20 \times 10^{7}$ & $0.32 \sim 0.65$ \\
(Wood-based) & Lower part & $1.11 \sim 35 \times 10^{5}$ & $0.29 \sim 0.35$ \\
HM BAC & Upper part & $0.30 \sim 20 \times 10^{7}$ & $0.59 \sim 0.82$ \\
(Coal-based) & Lower part & $1.12 \sim 30 \times 10^{5}$ & $0.22 \sim 0.30$ \\
DS BAC & Upper part & $1.20 \sim 34 \times 10^{7}$ & $0.61 \sim 1.10$ \\
Coal-based) & Lower part & $1.25 \sim 42 \times 10^{5}$ & $0.31 \sim 0.60$ \\
\hline
\end{tabular}

Values are expressed as average from four measurements during one year.

MJ: Myungjang Water Plant, HM: Hoamyung Water Plant, DS: Duksan Water Plant

plant 조사보다는 낮게 나타났다. 정수장별(활성탄 종류별)로 는 표층을 기준으로 하여 덕산 $\mathrm{BAC}$ (석탄계)가 $3.4 \times 10^{8}$ $\mathrm{CFU} / \mathrm{g}$ 으로 세균 생체량이 가장 많았으며, 다음으로 명장(목 탄계), 화명(석탄계) 순으로 나타났다. 그리고 세균 활성도는 표층에서 $0.32 \sim 1.10 \mathrm{mg}-\mathrm{C} / \mathrm{m}^{3} \cdot \mathrm{h}$, 저층에서 $022 \sim 0.60 \mathrm{mg}-\mathrm{C} /$ $\mathrm{m}^{3} \cdot \mathrm{h}$ 로 나타나, Servais 등[22]이 조사한 20 60 mg-C/m $\mathrm{m}^{3} \cdot \mathrm{h}$ 보다는 낮은 경향을 보였다. 활성탄 종류별로는 석탄계인 덕 산 $\mathrm{BAC}$ 가 최고 $1.10 \mathrm{mg}-\mathrm{C} / \mathrm{m}^{3} \cdot \mathrm{h}$ 의 활성을 보였다. 세균의 생체량과 활성도에 대한 실험 결과로 볼 때 세균은 주로 $\mathrm{BAC}$ 여과표층에 더 많이 분포하고 있음을 알 수 있었고 세균 생체 량이 많을수록 세균 활성도 또한 높은 것으로 나타나 생체량 과 활성도는 상관관계가 있음을 알 수 있었다.

그리고 활성탄 종류별로 생체량이 차이가 나는 주된 이유는 세균이 부착과 증식를 하는데 필요한 영양물인 수중의 유기물 질이 활성탄에 흡착하는 비율이 다르기 때문인 것으로 추정된 다. 이번 조사결과 석탄계인 덕산 $\mathrm{BAC}$ 가 가장 높았는데 이는 앞서 $\mathrm{DOC}$ 제거효율도 가장 높은 것으로 조사된 결과와 비슷
한 경향을 보여 부착세균 생체량과 $\mathrm{DOC}$ 제거효율과는 상관 관계가 있는 것으로 확인되었다[16,21].

\section{정수장별(활성탄 재질별) 부착세균 동정 및 SEM 분석}

정수장별(활성탄 재질별)로 부착세균의 동정 결과를 Table 4 에 나타내었는데, 배양적 방법으로 15종의 세균을 분리하였다. 각각의 활성탄에서 그람 음성 세균인 Pseudomonas 속이 가장 많이 분포하는 것으로 나타났고, 그 다음으로 Chryseomonas 속, Flavobacterium 속, Alcaligenes 속, Acinetobacter 속, Sphingomanas 속 등의 순으로 동정되었다. 이는 Stewart 등[24] 이 조사한 연구결과 즉 생물활성탄에 부착된 세균으로는 주로 Pseudomonas, Alcaligenes, Bacillus, Acinetobacter, Aeromonas, Chromobacterium 속 등이 있는 것으로 알려진 결과와 비슷한 경향을 보였다. Pseudomonas속은 가장 큰 집단인 $\gamma$ -proteobacteria에는 속하는 세균으로 다양한 생리학적 유형을 보이는 것으로 알려져 있는데 이번 조사에서 석탄계인 덕산 $\mathrm{BAC}$ 에는 Pseudomonas vesiculari와 Pseudomonas cepacia, 같은

Table 4. Distribution of bacteria isolated in different BAC types

\begin{tabular}{lccc}
\hline Bacterial identification & MJ BAC (Wood-based) & HM BAC (Coal-based) & DS BAC (Coal-based) \\
\hline Acinetobacter haemolyticus & - & + & + \\
Acinetobacter alcaligenes & - & + & + \\
Aeromonas hydrophila & - & + & + \\
Alcaligenes odorans & - & + & + \\
Chryseomonas luteola & ++ & + & + \\
Flavobacterium breve & + & + & + \\
Flavobacterium indolgenes & + & + & + \\
Flavobacterium menigosepicum & - & + & + \\
Pasteurella haemolytica & + & + & + \\
Pseudomonas vesicularis & + & + & + \\
Pseudomonas aureofaciens & + & + & + \\
Pseudomonas fluorescens & + & ++ & ++ \\
Pseudomonas cepacia & + & + & + \\
Sphingomonas paucimobilis & + & + & + \\
Stenotrophomonas maltophilia & + & +
\end{tabular}

※ Presence of the bacteria is detected in 1999. Symbol " $++"$ is expressed as a dominant species. Symbol " + " is expressed as a detectable species. Symbol "-" is expressed as a non-detectable species. 
석탄계인 화명 $\mathrm{BAC}$ 에는 Pseudomonas cepacia가 우점한 것으로 나타났으나 목탄계인 명장 $\mathrm{BAC}$ 는 덕산 및 화명 정수장과는 다르게 Chryseomonas luteola가 우점종으로 나타났다. 이렇게 $\mathrm{BAC}$ 종류별로 부착세균의 우점종이 다른 이유는 활성탄의 세공 크기, 표면 조직, 유속률 등의 차이에 의해 세균이 활성탄 에 부착할 수 있는 환경 조건이 다르기 때문인 것으로 판단된 다. 특히 조사된 부착세균 중 가장 우점한 Pseudomonas cepacia 는 $\mathrm{BAC}$ 에 부착된 유기물을 제거하는데 가장 탁월한 능력을 가지고 있다고 보고되고 있다[24].

그리고 SEM 사진 분석결과로는 활성탄 표면에 부착된 세 균들에 대하여 형태학적인 특성만을 나타내기 때문에 정확한 구분은 힘들지만 명장 $\mathrm{BAC}$ (목탄계 재질 활성탄)이 덕산 정수 장 $\mathrm{BAC}$ (석탄계 재질 활성탄)에 비하여 단조로운 세균 군집과 적은 개체수를 가지는 것을 관찰할 수 있었다. 저층보다는 주 로 표층에 세균이 분포하였고, 구균 보다는 간균이 많이 존재 함을 알 수 있었다(Fig. 2).

본 연구에서 생물활성탄 부착세균의 정수장별 분포실태 를 조사한 결과 생물활성탄 처리공정의 효과여부를 평가하

\section{A}

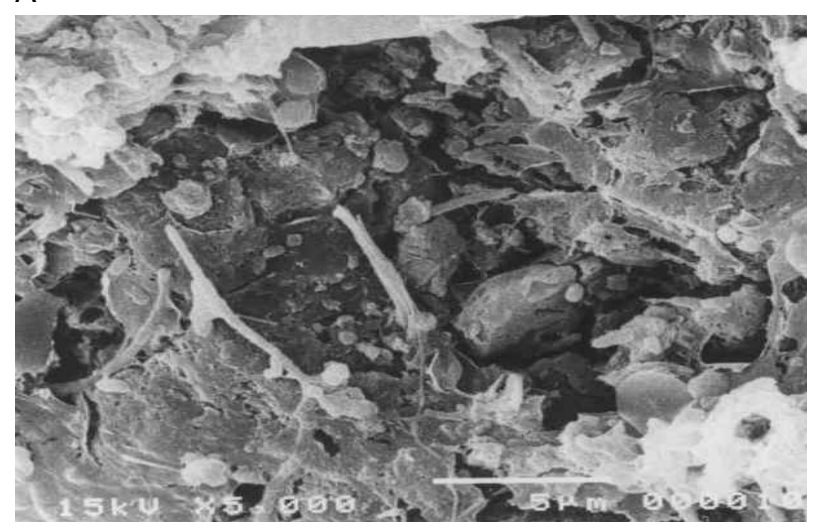

B

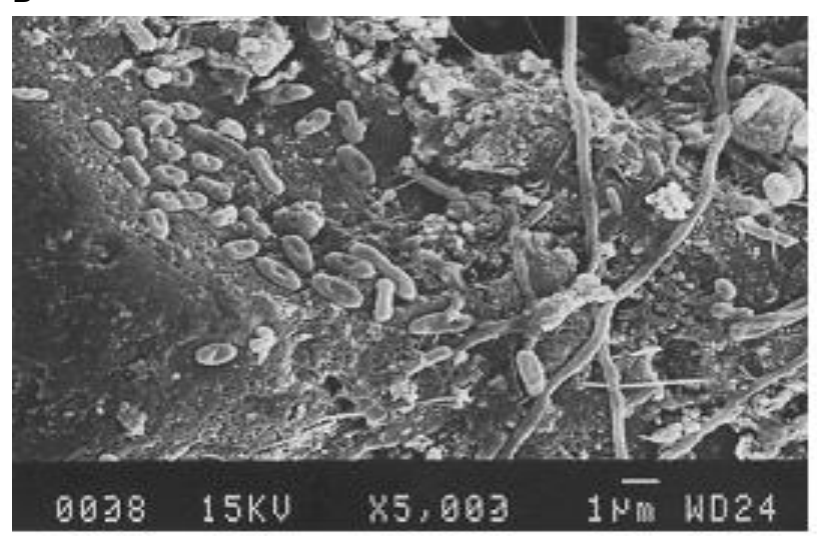

Fig. 2. SEM photograph of attached bacteria on BAC. A: MJ BAC (Wood-based), B: DS BAC (Coal-based). MJ: Myungjang Water Plant, DS: Duksan Water Plant
는 중요한 항목인 DOC 제거효율의 극대화를 위해서는 석 탄계 재질인 덕산 및 화명 정수장의 경우 주기적인 생물활 성탄 재생 및 교체를 통해 유기물질의 흡착능을 유지하여야 할 것으로 생각되며, 목탄계 재질인 명장 정수장은 석탄계 활성탄 도입에 대한 타당성을 조사하는 것이 바람직할 것이 라고 판단된다.

\section{References}

1. Adamson, A. W. 1982. Physical Chemistry of Surfaces. 4th Ed. John Wiley \& Son Inc. NY, USA.

2. Aiken, G. R., McKnight, D. M., Wershaw, R. L. and MacCarthy, P. 1987. Humic Subtances in Soil, Sediment and Water. Wiley-Intersciece. NY, USA.

3. Bell, R. T., Ahlgren, G. M. and Ahlgren, I. 1983. Estimating bacterioplankton production by the $\left[{ }^{3} \mathrm{H}\right]$ thymidine incorporation in a eutrophic Swedish Lake, Appl. Environ. Microbiol. 45, 1709-1721.

4. Boley, A., Unger, B., Muller, W. R., Kuck, B. and Deger, A. 2006. Biological drinking water treatment for nitrate and pesticide(endosulfan) elimination. Water Sci. Technol : Water Suppl. 6, 123-127.

5. Bouvier, T. and Giorgio, P. A. D. 2003. Factors influencing the detection of bacterial cells using fluorescence in situ hybridization (FISH): a quantitative review of published reports. FEMS Microbiol. Ecol. 44, 3-15.

6. Chrzanowski, T. H. and Hubbard, J. G. 1988. Primary and bacterial secondary production in a south-western reservoir. Appl. Environ. Microbiol. 54, 661-669.

7. Dussert, B. and Van Stone, G. 1994. The biological activated carbon process for water purification. Water Eng. Manage 141, 22-24.

8. Falkentoft, C. M., Muller, E., Amz, P., Harremoes, H., Wwlderer, P. A. and Wuertz, S. 2002. Population changes in a biofilm reactor for phosphorus removal as evidenced by the use of FISH. Water Res. 36, 491-500.

9. Fuhrman, J. A. and Azam, F. 1982. Thymidine incorporation as a measure of heterotrophic bacterio-plankton production in marine surface waters: evaluation and field results. Mar. Biol. 66, 109-120.

10. Ghosh, U., Weber, A., Jensen, J. and Smith, J. 1999. Granular activated carbon and biological active carbon treatment of dissolved and sorbed polychlorinated biphenyls. Water Environ. Res. 71, 232-240.

11. Graham, N. 1999. Removal of humic substances by oxidation/biofiltration processes-a review. Water Sci. Technol. 40, 141-148.

12. Kihn, A., Andersson, A., Laurent, P., Servais, P. and Prévost, M. 2002. Impact of filtration material on nitrification in biological filters used in drinking water production. $J$. Wat. Suppl:: Res. Technol. Aqua. 51, 35-45.

13. Krieg, N. R. and Holt, J. G. 1984. Bergey's Manual of Systematic Bacteriology. Williams \& Wilins. Baltimore, USA.

14. Melin, E., Eikebrokk, B., Brugger, M. and Ødegaard, H. 2002. 
Treatment of humic surface water at cold temperatures by ozonation and biofiltration, Water Sci. Tech: Wat. Supply 2, 451-457.

15. Nerenberg, R., Rittmann, B. E. and Soucie, W. J. 2000. Ozone/biofiltration for removing MIB and geosmin. J. Am Water Works Assoc. 92, 85-100.

16. Park, E. J. 1997. A Study on the Variation of $A_{M W D}$ after each stage in BAC Pilot-plant. Theme of Master in National Busan University.

17. Park, J. Y. 1994. Drinking Water Microbiology. pp. 385-396, Chemical Engineering Research Corporation, Seoul.

18. Rice, R. G. and Robson, C. M. 1982. Biological Activated Carbon. Lewis Publishers, Boca Raton, Florida.

19. Rigway, H. F. and Olsan, B. H. 1981. Scanning electron microscope evidence for bacterial colonization of a drinking water distribution system. Appl. Environ. Microbiol. 41, 274-287

20. Sakoda, A., Wang, J. and Suzuki, M. 1996. Microbial activity in biological active carbon bed by pulse responses. Water Sci. Technol. 34, 213-222.

21. Scholz, M. and Martin, R. 1997. Ecological equilibrium on biological active carbon. Water Res. 31, 2959-2968.

22. Servais, P., Billen, G., Ventresque, C. and Bablon, G. P. 1991. Microbial activity in GAC filters at the Choisy-Roi treatment plant. J. Am Water Works Assoc. 75, 62-68.

23. Servais, P., Billen, G., Bouillot, P. and Benezet, M. 1992. A pilot study of biological GAC filtration in drinking-water treatment. Aqua 41, 163-168.

24. Stewart, M. H., Wolfe, R. L. and Means, E. G. 1990. Assessment of bacteriological activity in carbon treatment of drinking water. Appl. Environ. Microbiol. 56, 3822-3823.

25. Takeuchi, Y., Mochidzuki, K., Matsunobu, N., Kojima, R., Motohashi, H. and Yoshimoto, S. 1997. Removal of organic substances from water by ozone treatment followed by biological active carbon treatment. Water Sci. Technol. 35, 171-178.

초록 : 생물활성탄 부착세균 분포 실태에 관한 연구

박홍기*·정은영 · 차동진 · 김정아 · 빈재훈

(부산광역시 상수도사업본부 수질연구소)

정수처리 공정에서 생물활성탄(BAC) 공정은 미생물의 유기물 제거능을 극대화시킨 일종의 생물여과 공정이 다. 본 연구는 낙동강 원수를 이용하여 재질이 다른 생물활성탄을 사용하고 있는 정수장을 대상으로 세균 군집을 조사하였다. 실험결과 석탄계 재질의 $\mathrm{BAC}$ 부착세균 생체량 및 활성도가 각각 $1.20 \sim 34.0 \times 10^{7} \mathrm{CFU} / \mathrm{g}, 0.61 \sim 1.10$ $\mathrm{mg}-\mathrm{C} / \mathrm{m}^{3} \cdot \mathrm{h}$ 의 범위를 보여 세균 생체량과 DOC 제거율은 석탄계 재질이 가장 높은 것으로 나타났다. 부착세균 을 동정한 결과 Pseudomonas 속이 우점하였으며, 그 다음으로 Chryseomonas 속, Flavobacterium 속, Alcaligenes 속, Acinetobacter 속, Sphingomonas 속 등의 순으로 동정되었다. 그리고 Pseudomonas cepacia는 석탄계 재질, Chryseomonas luteola는 목탄계 재질의 우점세균으로 조사되었다. 